\title{
Erratum to: Geovisualization of Nonresident Students' Tabulation Using Line Clustering
}

Zainura Idrus, Zanariah Idrus, Siti Zaleha Zainal Abidin, Nasiroh Omar and Nur Syamimi Aziah Mohamat Sofee

Erratum to:

Chapter "Geovisualization of Nonresident Students' Tabulation Using Line Clustering" in:

N. A. Yacob et al. (eds.), Regional Conference on Science, Technology and Social Sciences (RCSTSS 2016), https://doi.org/10.1007/978-981-13-0074-5_9

The original version of the book was inadvertently published without the second author name "Zanariah Idrus" in Chapter 9, which has been now included. The erratum chapter and the book have been updated with the change.

The updated online version of this chapter can be found at https://doi.org/10.1007/978-981-13-0074-5_9 